International Journal of Agriculture, Environment and Bioresearch

Vol. 4, No. 06; 2019

ISSN: $2456-8643$

\title{
EFFECT OF PLANT EXTRACTS ON POST-HARVEST SHELF LIFE AND QUALITY OF TOMATO FRUITS IN STORAGE AT WUKARI, TARABA STATE
}

\author{
${ }^{1}$ Tunwari B.A., ${ }^{1}$ Labaran A.G. and ${ }^{2}$ Aji, P.O., ${ }^{2}$ Kyugah J.T., ${ }^{3}$ Williams W.S. \\ ${ }^{1}$ Department of Crop Production and Protection, Federal University Wukari, Katsina - Ala Road, P.M.B. 1020, \\ Wukari, Taraba State, Nigeria. \\ ${ }^{2}$ Department of Biological Science, Federal University Wukari, Katsina - Ala Road, P.M.B. 1020, Wukari, Taraba \\ State, Nigeria. \\ ${ }^{3}$ Adamawa State Polytechnic, P.M.B. 2146 Yola, Adamawa State, Nigeria
}

http://doi.org/10.35410/IJAEB.2019.4492

\begin{abstract}
Tomato fruit are vested with problems of field and storage rot. Among these are Aspergillus niger and A. flavus which are omnipresent in all tomato growing regions. Experiments were carried out in 2017 and 2018 on the effect of plant extracts and varieties in extending the shelf life of tomato fruits in the study area. Tomato fruits samples consisting of two varieties (Seria and Tangino) obtained from three different locations namely New Market, Old Market, and Federal university gate (FUW) were used for the experiments. The result showed that Neem leaf extract, Garlic bulb extract, and Ginger extract were effective in reducing mycelia growth, extended shelf life and maintain the quality of tomato fruits during storage. Significant variations were observed among the varieties in relation to most of the parameters studied. Irrespective of treatment, weight loss, postharvest decay, marketability, shelf life, and firmness decrease with increase in storage duration. The Ginger extract had a significant effect in preventing tomato rot disease compared to Neem leaf extract. The finding indicates that Ginger extract can be used to extend shelf life and quality of tomato fruits beyond their natural limit.
\end{abstract}

Keywords: Plant extracts, Post-harvest, Shelf life, Tomato fruits.

\section{INTRODUCTION}

Tomato (Lycopersicon esculentum Mill.) also known as Tamato in Hausa, Tomereto in Igbo, and Tamati in Yoruba, which belong to the family solanaceae and order solanales, is one of the most popularly cultivated and extensively consumed vegetable crops in the world (Grandillo et al.1999; Agrios, 2005). It is native of South America, but was introduced into West Africa by Portuguese trader and freed slaves from West Indies.. The major producing areas in Nigeria lie between latitude $7.5{ }^{\circ} \mathrm{N}$ and within a temperature range of $25-34{ }^{\circ} \mathrm{C}$ (Agrios, 2005; villarel, 1980). These areas include most State in Northern Nigeria namely, Bauchi, Benue, Borno, Kaduna, Kano, Plateau, Sokoto and a few southern State in Nigeria like Kwara and Oyo (Denton and Swarup, 1983; Olanrewaju and Swamp, 1980).

Tomato (Lycopersicon esculentum) can be eaten raw as Salads or as an ingredient in many dishes and in drinks (Alam et al; 2007). Tomato and tomato based foods provide a wide variety 
of nutrients and many health related benefits to the body.Tomato is rich in vitamins (John et al. 2010; Bugel, 2003). In regions where it is being cultivated and consumed, it constitutes a very essential part of people diet. Tomato production accounts for about 1.8million hectare of harvested land area globally with an estimated production of 162million tons (FAOSTAT, 2014). Global production is about 89.8 million metric tonnes from area of about $3,170.000$ ha (Samuelet al., 2011).Nigeria is second largest producer of tomato in Africa second only to Egypt and $13^{\text {th }}$ in the world and produces 6million tonnes of tomato annually prior to 1990 . Nigeria is second largest producer of tomato in Africa where a total area of one million hectares is used for tomato cultivation every year (Babalola, et al. 2010). Tomato accounts for about $18 \%$ of the average daily consumption of vegetables in Nigeria, and may be pressed into pastes or purse which is used for cooking and in the production of fruit drinks (Babalola et al. 2010). Research has shown that associated pathogens of tomato fruit rot in Northern Nigeria were Alternaria solani, Septoria lycopersici, Corticium rolfsii, Aspergillusflavus, Aspergillus niger, Fusarium solani, Penicillium sp, Lasiodiplodia theobromae. The production of tomato in Taraba is low; hence the community and its environment depend on the produce being brought from neighbouring states. Poor handling, transportation and storage have been responsible for reduced shelf life of tomato fruits due to rot. Among the various options, plant products have been found to contain biochemical constituents that are fungitoxic, which are equal efficiency with synthetic fungicide, less expensive, biodegradable, ecofriendly without causing hazards to the environment (Amadioha and Obi, 1999; Okigbo, 2009). The research study could provide information concerning fungal pathogens causing postharvest tomato fruits rot to farmers in the study area and other nearby farmers. Investigation on the antifungal properties of neem, garlic, and ginger could serve as a relative alternative to the use of synthetic chemicals to extend the shelf life of tomato so as to reduce or eliminate loss due to postharvest rot cause by phytopathogenic fungi and the resultant economic loss to the farmers, traders and consumers.

\section{MATERIALS AND METHODS}

\subsection{Collection of tomato fruits}

Tomato fruits with symptoms of rots were randomly collected from three locations namely: Federal University gate, New Market and Old Market WukariTaraba State. The varieties obtained included Seria and Tangina. Fresh and healthy tomato fruits were also obtained from the markets and packed into sterile polythene bags already lined with soft paper according to varieties and taken to the laboratory for further studies.

\subsection{Isolation and identification of micro-organisms responsible for tomato fruit rots}

Small sizes of about $3 \mathrm{~mm} \times 3$ mmwere cut with sterile scalpel or scissor from freshly advancing lesion (moving from the healthy portion to the diseased portion where fungi is likely to be more active.) of tomato rot infected fruits and surface sterilized by dipping in $1 \%$ sodium hypochlorite $(\mathrm{NaOCl})$ solution for one minute. After that the sterilized pieces were removed and rinsed 3 times in sterile distilled water then placed on sterile paper towels to dry. $15 \mathrm{mls}$ of the moltenpotato Dextrose Agar (PDA),already prepared according to manufacturer's instructions, was poured into each $9 \mathrm{~cm}$ petri-dishes and were allowed to cool before inoculation. About 0.16 
Vol. 4, No. 06; 2019

ISSN: $2456-8643$

$\mathrm{g} / \mathrm{l}$ streptomycin sulphate powder was added to suppress bacteria contamination (Lester et al., 2008). The sterilised tomato diseased pieces were then plated in the various dishes containing the PDA media. Three replicates were made for each sample. The inoculated plates were incubated at ambient temperature or room temperature $\left(25-28{ }^{\circ} \mathrm{C}\right)$ and observations were made for microbial growth. After 5 - 7 days of growth, sub culturing was done to obtain pure cultures of the isolates as reported by Ogo-Oluwa and Liamngee (2016). From these pure cultures, inoculums of the different fungal species isolates were obtained for the pathogen city tests. Subcultures were made aseptically from the plates into similar PDA plates and were inoculated under similar conditions as in 3.2.3 until pure cultures were obtained. Identification was done microscopically and macroscopically. Colony characteristics such as appearance, change in medium colour and culture growth pattern were observed. Shape of the conidia and conidiophores were taken note of. This was done by teasing small portions of the fungal cultures using loop and needles, mounted on lactophenol and cotton blue on clean slides covered with clean cover slips and then viewed microscopically. These features were matched with standards described by Barnett and Hunter (2006) as reported by Ogo-Oluwa and Liamngee (2016).

\subsection{Collection and extraction of plant materials}

Neem leaves were collected from around and within Federal University WukariTaraba State, while ginger rhizomes were purchased from New Market, Wukari. The plant leaves were dried for three days at room temperature $\left(26-28^{\circ} \mathrm{C}\right)$ to reduce the moisture; these dried leaves were ground using pistil and mortar into powder. The ginger rhizomes were dried at room temperature $\left(26-28^{\circ} \mathrm{C}\right)$ for seven days and ground separately using a grinder to get powder. To get concentrated solution of these plant extracts $40 \mathrm{~g} / \mathrm{l}$ of the powdered form of the extracts were dissolved in 1 litter of distilled water separately, vigorously agitated and left for 24 hours to stud before filtration using muslin cloth. The filtrates were used as the plant extracts in the experiment.

\subsection{Effects of Plant Extracts on naturally infected development on tomato fruits}

This was a factorial experiment consisting of fresh and healthy tomato fruits from two varieties (Seria and Tangino) purchased from NewMarket in Wukari, and twoplant extract treatments namely neem leaf extract, ginger extract and control (sterile water); replicated threetimes in a completely randomized design (CRD). Tomato fruits used in this study were selected for uniformity in size, appearance, ripeness and the absence of physical defects; and washed in clean water to remove dirt, rinsed again in water and kept to air-dry before treatment. Tomatoes were dipped into the solutions of various plant extract treatments at concentration of $40 \mathrm{~g} / 100 \mathrm{ml}$ of distilled water for $1 \mathrm{~min}$ at room temperature $\left(25^{\circ} \mathrm{C}\right)$ and air dried. Fruits were dipped into sterile distilled water, (to serve as control) and then air dried. Treated tomatoes (20 fruits per plot) were placed in $1.5 \mathrm{~L}$ plastic boxes and stored at $25^{\circ} \mathrm{C}$ (for 12 days). The two varieties of tomato fruits were used for each treatment, each replicated three times and arranged in completely randomized design with each plot containing twenty fruits. Untreated tomato fruits were used as control. A total of six treatment combinations replicated three times were the layout 
of the experiment.The percentage of infected fruits was recorded when about $50 \%$ of control fruits had decayed.Data collected include:

2.4.1Postharvest decay percentage (PDP): Postharvest decay or rotting was determined by visual evaluation for symptoms of decay during the storage period. Samples having symptoms of decay were counted, recorded and expressed in percentage as shown below.

$\mathrm{PDP}=$

Number of fruits Decaying x 100

Total number of fruits

2.4.2Weight percentage(WP): Tomato fruits were weighed at the beginning and during the storage interval using weighing balance. The difference between the initial and final weight of the fruits was considered as total weight loss during the storage interval and expressed as a percentage.

$\mathrm{WP}=$

$\underline{\text { Initial weight - final weight } \mathrm{x} 100}$

Initial weight

2.4.3Shelf life: Shelf lives of tomato fruits were evaluated by counting the number of days tomato fruits were still acceptable for marketing. It was decided based on appearance and spoilage of fruits.

2.4.4Firmness: Firmness of tomato fruits was determined by hand estimation using a numerical rating scale of $1-5$. Where $1=$ Very poor, $2=$ poor, $3=$ acceptable, $4=$ Good, and $5=$ Excellent.

2.4.5 Marketability: Based on descriptive quality attributes such as level of visible lesion, shriveling, smoothness and shininess of fruit, percentage of marketable fruits during the experiment was calculated by the formula.

Marketability of tomato fruit $=$ number of marketable fruits x 100

\subsection{Data analysis}

Total number of fruits

Data collected were subjected to two-way analysis of variance (ANOVA) of completely randomized design (CRD) for experimentsusing Genstat 8.1 (2005) statistical package. The treatment means that were significantly different were separated using Least Significant Difference (LSD) at $5 \%$ level of probability.

\section{RESULT AND DISCUSSION}

\subsection{Isolation and identification of associated fungi from rotten tomato fruits}

Two isolated fungi from tomato fruits were identified as,Aspergillusniger(Plate I) andAspergillusflavus (Plate II). These features were matched with standards described by Barnett and Hunter (2004) as reported by Ogo-Oluwa and Liamngee (2016). 
International Journal of Agriculture, Environment and Bioresearch

Vol. 4, No. 06; 2019

ISSN: $2456-8643$

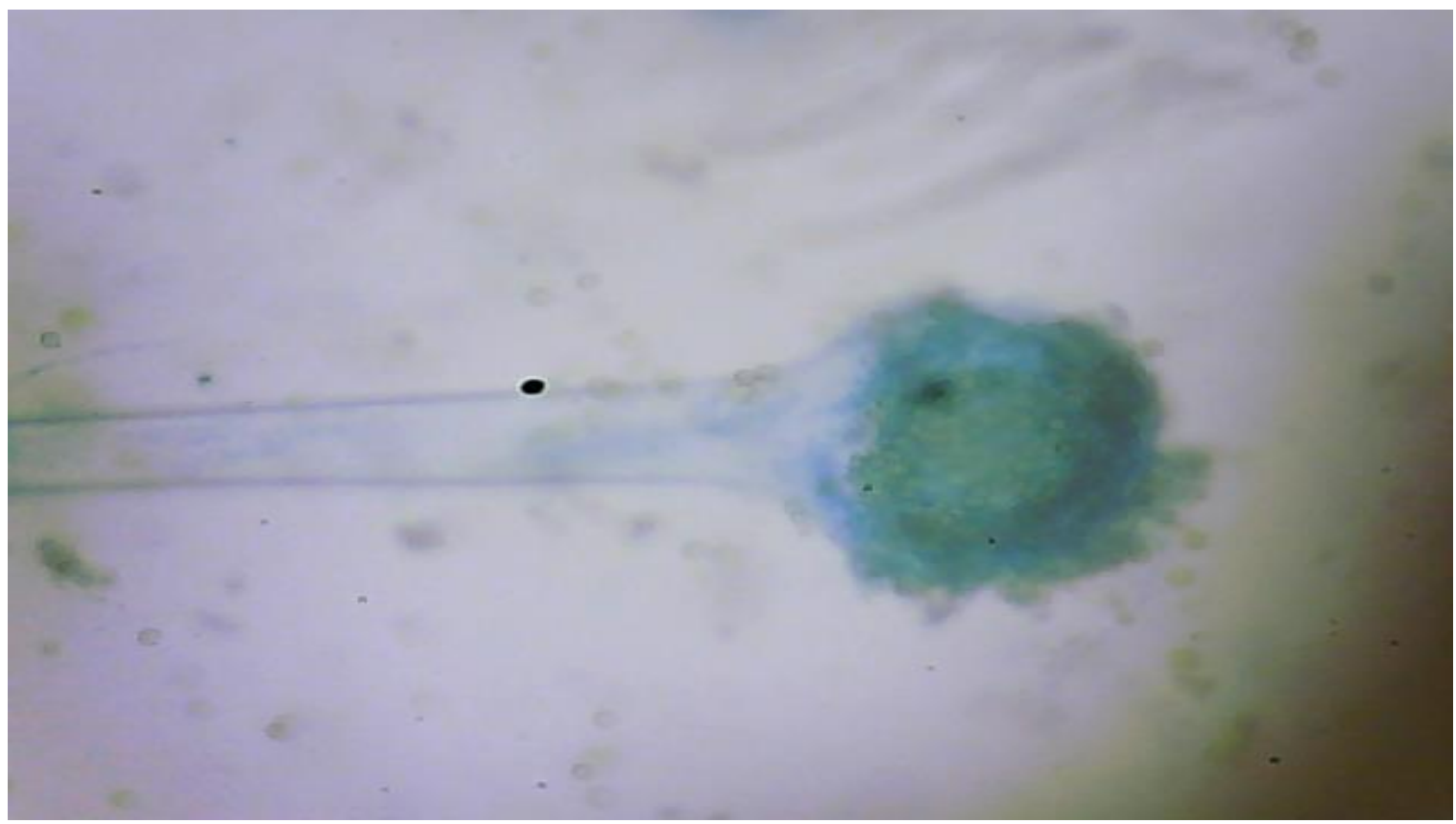

Plate I: Micrograph of Aspergillus niger at Wukari Taraba State

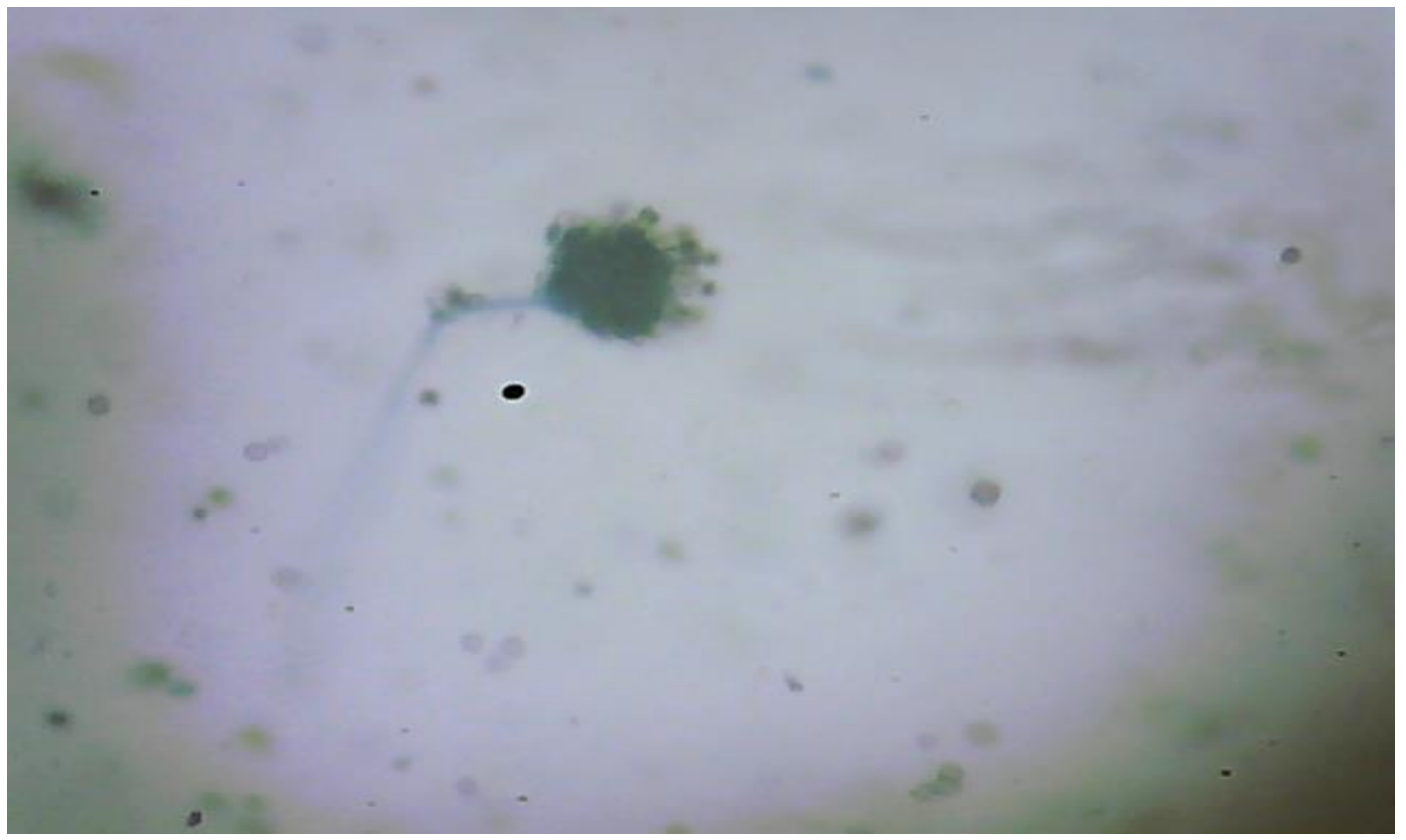

Plate II: MicrographAspergillusflavusat WukariTaraba State

3.2 Effect of plant extractand variety on post-harvest decay (PDP) of Tomato Fruits.

Effects of plant extracts and varieties on post-harvest decay percentage (PDP) of tomato fruits are presented in Table 1. The results showed no significant effect of varieties on PDP of tomato fruits from day $4-10$ and $16-24$ duration of storage. However, Seria tomato variety 
statistically and highly statistically reduced post-harvest decay in day $12(68 \%)$ and day 14 (72 $\%$ ) compared with Tangino with $74 \%$ and $76 \%$ respectively (Table 1). Ginger rhizome extract was seen to highly reduce post-harvest decay percentage compared to neem extract and control throughout the duration of storage from 4 to 24 day duration of storage (Table 1).Tomato fruits treated with Ginger rhizome extract showed low post harvest decay. There were observed differences between the number of decayed fruits in both treated and control tomato fruits. Control fruits were completely rotten on day 24 of storage while the treated fruits still retained their colour and number.

The efficacy of Ginger rhizome extract in reducing post-harvest decay is in agreement with works by Zakki et al. (2017) who inferred that Neem powder was able to reduce postharvest decay when compared to control. The ability of Ginger rhizome extract to decrease the decay level of tomatoes is an indication that Ginger rhizome extract can serve as a possible alternative in the prevention of tomato decay by pathogens. This observation is in agreement with the reports of Raheja and Thakore (2002) who reported that extract from medicinal plants like Allum sativum (cloves), Azadirachta indica (leaves), Mentha arvensis (leaves) and Psoralea corylifolia were found most effective in preserving plant fruits from attack by pathogenic and environmental factors.

\subsection{Effect of plant extractand variety on weight loss (\%) of Tomato Fruits}

Results in Table 2 presented highly varietal and plant extract effects on tomato fruits during storage at Wukari in 2017 and 2018. Seria tomato variety and ginger rhizome extract were found to consistently reduce weight loss of tomato fruits between $5.62-30.92 \%$ and $5.17-$ $26.90 \%$, compared to variety Tangino $(5.85-52.69 \%)$ and control non plant extract treatment $(5.87-38.60 \%)$ respectively throughout the storage duration of between 4 to 24 days. There was progressive weight loss among Seria and Tanginovarieties in the course of this research. This is in agreement with Atta-Aly and Bretch (1995) whose statement revealed that there is significant weight loss as ripening progressed. Similar findings were also reported by Meseret et al. (2012), Tefera et al. (2007) and Hiruet al. (2008) that weight loss of fruits increased as storage period advanced. The variation in weight loss among the different varieties considered could be due to the variation in the pericarp thickness as thin pericarp leads to aggravating weight loss and rate of respiration among the varieties because higher rate of respiration is related to higher loss of stored food and dry matter of the fruits. Thick pericarp and genetic makeup on the other hand, reduces weight loss as evident in the seria variety thus reducing the degree of moisture loss and shrivelling.

\subsection{Effect of plant extractand variety on shelf life of Tomato Fruits}

From the results in the Table 3 it can be deduced that seria tomato fruits treated with ginger rhizome extract has the ability to highly significantly prolong the shelf life of tomato fruit from 8 to $10 \%$ and 7 to $11.17 \%$ compared to Tangino variety and control ( without plant extract ) respectively. Shelf life of the two varieties of tomato fruits considered in this study was quite significant. Seria variety treated with Ginger rhizome extract had a significant shelf life as compared to the control fruits. Treating tomato fruits with Ginger rhizome extract highly significantly increased it shelf life as seen in the number of days it took for complete spoilage of 
the fruits to occur. The result in this study is similar to the findings of Ejale and Abdullah (2004), who reported that treating tomato fruits with Neem significantly increased their shelf life. Irokanuloet al. (2015) also noted that tomato fruits treated with the powders of Moringaoleiferaplant parts had an extended storage life.

\subsection{Effect of plant extractand variety on firmness of Tomato Fruits}

Table 4 shows the results of plant extracts on fruits of tomato varieties taken at $4,6,8$, $10,12,14,16,18,20,22$ and 24 days interval at wukari. Though tomato fruits treated with neem and Ginger rhizome exhibited better degree of firmness, they were not found to be significant compare with control treatment. Firmness of the tomato fruits used in the study was also considered as a quality parameter to test the preservative ability of plant extracts. This is due to the fact that most buyers of tomatoes tend to feel the tomato fruits before buying especially after colour observation. In terms of firmness, Seriavariety and ginger rhizome extract seem to exhibit some degree of firmness after the experimental period elapsed. The other treatments especially control lost their firmness during storage.This decrease in firmness can be attributed to the higher rate of metabolic activities and activity of cell wall degrading enzymes that loosens the fruit skin which result in higher permeability of the cell for higher rate of moisture loss (Zakkiet al., 2017).

\subsection{Effect of plant extractand variety on Marketability of Tomato Fruits}

Results of the effect of plant extract and varieties on marketability of tomato fruits under storage showed highly statistically significant difference at day 22 and 24 of the storage duration (Table 5). The results revealed that $3 \%$ of Seria variety is still marketable at 22 and 24 storage duration, compared with Tangino with only $1 \%$. It was also revealed that $3.5 \%$ of fruits treated with Ginger rhizome extract were still marketable at days 22 and 24 of the storage duration when compared with control (0.75\%). Zakkiet al. (2017) also observed the highest marketability on UTC tomato variety and fruits treated Neem leaf powder compared with the control fruits.

\section{CONCLUSION}

It can therefore, be concluded that plant extracts like garlic bulb extract, neem leaf extract and ginger rhizome inhibited radial growth of the pathogens and able to extend the shelf life and the quality of tomato fruits beyond their known natural limits. The research findings have provided baseline information on the use of plant extract in post-harvest preservation of fruits. The ability of plant extract to decrease the decay level of tomato is an indication that plant extracts can serve as a possible alternative in the prevention of tomato decay by pathogens.Researches using more tomato varieties with a view to determining the ones with better genetic constituents that are resistance to tomato rot causing organisms. Further investigations are needed on other methods of extraction(like hot water, alcohol solvents), the rate and efficacy of bioactive constituents, frequency and method of application of the different plant extracts.

\section{REFERENCES}

Agrios, G.N. (2005). Plant pathology, Academic press, New York, USA 
Alam, T., Tanweer, G. and Goyal, G.K. (2007). Stewart Postharvest Review, Packaging and storage of tomato puree and paste. Research article, 3(5): 1-8

Amadioha, A.C. and Obi, I.V. (1999) Control of Anthracnose disease of cowpea by CymBopogon citrates and Ocimumgratissimum. Acta psychological Et entomological Hungarica 34, 85-89.

Atta-Aly, M. and Brecht, J. (1995), "Effects of Postharvest high temperature on tomato fruit ripening and quality", Advances in Applied Science Research, Vol. 2 No.4, pp. 217-220.

Babalola, D. A., Makinde Y. O.,Omonona B. T. and Oyekanmi, M.O. (2010). Determinants of post-harvest losses in tomato production: a case study of Imeko-Afon local government area of Ogun state. Acta SATECH 3(2): $14-18$

Barnett, H.L. and Hunter, B.B. (2006). Illustrated Genera of Imperfecti Fungi. American Phytopathology Society (APS) Press, St. Paul Minnesota Fourth Edition, p 128.

Bugel, S. (2003). Vitamin K and bone health. Proc. Nutri Soc. 62, 839-843.

Denton O.A.andSwarup V (1983). Tomato cultivation and its potential in Nigeria. Acta Hort., $123,257-263$

Ejale, A. and Abdullah, H. (2004), "Preservation of ripe tomato (Lycopersicon esculentumMill) fruits with dried leaf powder of Neem (AzadirachtaindicaA. Juss)", Nigerian Journal of Applied Science, Vol. 22, pp. 344-350.

FAOSTAT (2014). Global tomato production in 2012. Rome, FAO.

Grandillo, S., Zamir, D. andTanksley, S.D. (1999) Genetic improvement of processing tomatoes: A 20 years perspective. Euphytica 110: 85-97

Hiru, G., Seyoum, T. and Kebede, W. (2008), "The effect of cultivar, maturity stage and storageenvironment on quality of tomatoes", Ethiopian Journal of Food Engineering, Vol. 87 No. 4, pp. 467- 468.

Irokanulo, E., Egbezien, I. and Owa, S. (2015), "Use of Moringaoleiferain the preservation of Fresh Tomatoes", Journal of Agriculture and Veterinary Science, Vol. 8 No. 2, pp. 127132.

John, D, Suthin, R.T., Usha, R.S. and Udhayakumar, R (2010). Role of defense enzymes activity in tomato as induced by Trichodermavirens against Fusarum wilt caused by Fusariumoxysporum F. SpLycopersici. J. Biopesticide, 3, 158-162.

Madari, S. and Singh, R.P. (2005). Management of mushroom pathogens through botanicals. Indian Phytopathologia, 38:189-191. 
Meseret, D., Ali, M. and Kassahun, B. (2012), "Evaluation of Tomato (LycopersiconesculentumMill) Genotypes for fruit quality and shelf life", The African Journal of Plant Science and Biotechnology, Vol. 3, pp. 50-56.

Ogo-Oluwa, A. and Liamngee, K. (2016). "Evaluation of bitter leaf (Vernoniaamygdalina) extract in the inhibition of fungi causing post-harvest rot of tomato fruits in Makurdi, Benue State, Nigeria", Der Pharmacia Lettre, Vol. 3 No.11, pp. 69-73.

Okigbo, R.N. (2009). Variation in phytochemical properties of selected fungicidal aqueous extract of some plant leaves in Kogi State, Nigeria. American Eurossian Journal of Sustainable Agriculture. 3(3):407-409.

Olanrewaju, D and Swamp, V (1980). Tomato cultivation and its potential in Nigeria. National Horticulture Research Institute Bulletin. Ibadan, Nigeria, 20pp

Raheja, S. and Thakore, B. (2002), "Effect of physical factor, plant extracts and bioagent on ColletotrichumgloeosporioidesPenz, the causal organism of anthracnose of Yam", Journal of Mycology and Plant Pathology, Vol. 32, pp. 293-294.

Samuel, A, Paul, C.S., Heuvelink, E.P. and Woldeamlak, A (2011). Opportunities and constraint of tomato production in Eritrea. Afr. J. Agric. Res. 6, 956-967.

Tefera, A., Seyoum, T. and Woldetsadik, K. (2007), "Effect of disinfection, packaging and storageenvironment on the shelf life of mango", Biosyst. Eng, Vol. 96 No. 2, pp. 201-212.

Villareal R.I. (1980). Tomato in the tropics. Wesview Press Boulder, Colorado U.S.A

Zakki Y.H., Kator L., Ameh L.O. and Terna D.A. (2017).Effect of Neem leaf powder on Postharvest shelf life and quality of tomato fruits in storage.International Journal of Development and Sustainability, Volume 6 Number 10 (2017): Pages 1334-1349.ISSN: 2186-8662 - www.isdsnet.com/ijds 
International Journal of Agriculture, Environment and Bioresearch

Vol. 4, No. 06; 2019

ISSN: 2456-8643

Table 1. Effect of plant extract and variety on post-harvest decay \% of tomato fruits during storage at wukari 2018

\begin{tabular}{|lllllllllllll}
\hline Treatment & Day4 & Day6 & Day8 & Day10 & Day12 & Day14 & Day16 & Day18 & Day20 & Day22 & Day24 \\
\hline Variety & & & & & & & & & & & \\
Seria & $2(8.33)$ & $4(18.33)$ & $7(32.78)$ & $7(35.00)$ & $14(68.33)$ & $14(72.22)$ & $15(76.11)$ & $16(78.33)$ & $(81.11)$ & $17(82.78)$ & $17(85.00)$ \\
Tangino & $1(7.22)$ & $1(13.33)$ & $7(34.44)$ & $8(40.56)$ & $15(73.89)$ & $15(76.11)$ & $16(77.78)$ & $16(78.89)$ & $(82.22)$ & $17(84.44)$ & $17(87.22)$ \\
LSD (5\%) & 2.71 & 4.02 & 3.83 & 2.10 & 3.20 & 2.10 & 1.71 & 1.21 & 2.10 & 1.71 & 1.21 & \\
Plant extract & & & & & & & & & & \\
Neem & $2(7.50)$ & $3(15.83)$ & $6(28.33)$ & $7(34.17)$ & $13(65.00)$ & $14(68.33)$ & $14(71.67)$ & $15(75.00)$ & $(75.00)$ & $16(77.50)$ & $16(80.83)$ \\
Ginger & $1(5.00)$ & $3(15.00)$ & $6(28.33)$ & $6(30.00)$ & $12(59.17)$ & $13(64.17)$ & $14(69.17)$ & $14(70.00)$ & $(73.33)$ & $15(75.00)$ & $(77.50)$ \\
Contol & $2.17(10.83)$ & $18(89.17)$ & $9(44.17)$ & $8(41.67)$ & $18(89.17)$ & $18(90.00)$ & $18(90.00)$ & $18(90.83)$ & $(96.67)$ & $20(98.33)$ & $20(100.00)$ \\
Mean & 7.78 & 18.33 & 33.61 & 37.78 & 71.11 & 74.17 & 76.94 & 78.60 & 81.67 & 83.61 & 86.11 \\
LSD\% & 3.32 & 4.92 & 4.69 & 2.57 & 3.92 & 2.57 & 2.10 & 1.48 & 2.57 & 2.10 & 1.48 & \\
\hline
\end{tabular}

Table 2 Effect of plant extract and variety on weight loss (\%) of tomato fruits during storage at wukari

\begin{tabular}{|c|c|c|c|c|c|c|c|c|c|c|c|}
\hline Treatment & Day4 & Day6 & Day8 & Day10 & Day12 & Day14 & Day16 & Day18 & Day20 & Day22 & Day24 \\
\hline \multicolumn{12}{|l|}{ Variety } \\
\hline Seria & 5.82 & 4.86 & 6.89 & 6.07 & 6.71 & 7.30 & 11.57 & 16.51 & 20.32 & 26.20 & 30.92 \\
\hline Tangino & 5.86 & 7.10 & 7.42 & 6.86 & 7.34 & 7.80 & 13.59 & 18.07 & 23.52 & 28.78 & 32.69 \\
\hline LSD (5\%) & 1.18 & 0.09 & 0.07 & 0.13 & 0.03 & 0.13 & 0.23 & 0.73 & 0.22 & 0.78 & 0.58 \\
\hline \multicolumn{12}{|c|}{ Plant extract } \\
\hline Neem & 6.88 & 6.72 & 7.02 & 6.43 & 7.02 & 7.52 & 11.77 & 16.45 & 20.36 & 24.83 & 29.92 \\
\hline Ginger & 5.17 & 5.67 & 6.13 & 5.52 & 5.80 & 6.37 & 10.88 & 14.85 & 18.53 & 22.82 & 26.90 \\
\hline Contol & 5.87 & 7.93 & 8.32 & 7.43 & 8.27 & 8.77 & 15.08 & 20.57 & 26.87 & 34.82 & 38.60 \\
\hline Mean & 5.74 & $6 ’ 77$ & 7.16 & 6.46 & 7.03 & 7.30 & 12.58 & 17.29 & 21.92 & 27.49 & 31.81 \\
\hline $\mathrm{LSD} \%$ & 1.45 & 0.11 & 0.09 & 0.15 & 0.04 & 0.16 & 0.28 & 0.89 & 0.27 & 0.95 & 0.71 \\
\hline
\end{tabular}

Table 3 Effect of plant extract and variety on shelf life of tomato fruits during storage at wukari 2018.

\begin{tabular}{|ll|}
\hline Treatment & Shelf life \\
\hline Tomato varieties & 10.00 \\
Tangino & 8.33 \\
LSD (5\%) & 0.54 \\
Plant extract & \\
Neem & 9.33 \\
Ginger & 11.17 \\
Contol & 7.00 \\
Mean & 9.17 \\
LSD\% & 0.66 \\
\hline
\end{tabular}


International Journal of Agriculture, Environment and Bioresearch

Vol. 4, No. 06; 2019

ISSN: 2456-8643

Table 4 Effect of plant extract and variety on firmness of tomato fruits during storage at wukari 2018

\begin{tabular}{|c|c|c|c|c|c|c|c|c|c|c|c|}
\hline Treatment & Day4 & Day6 & Day8 & Day10 & Day12 & Day14 & Day16 & Day18 & Day20 & Day22 & Day24 \\
\hline \multicolumn{12}{|l|}{ Variety } \\
\hline Seria & 4.00 & 3.11 & 3.22 & 3.00 & 3.33 & 3.33 & 3.33 & 3.33 & 3.33 & 2.67 & 2.67 \\
\hline Tangino & 4.00 & 3.33 & 3.33 & 3.00 & 3.00 & 3.00 & 2.67 & 2.67 & 2.67 & 2.33 & 2.00 \\
\hline $\operatorname{LSD}(5 \%)$ & - & 0.24 & 0.24 & - & - & - & - & - & - & - & - \\
\hline \multicolumn{12}{|c|}{ Plant extract } \\
\hline Neem & 4.00 & 3.00 & 3.00 & 3.00 & 3.00 & 3.00 & 3.00 & 3.00 & 3.00 & 3.00 & 2.00 \\
\hline Ginger & 4.00 & 3.67 & 4.00 & 4.00 & 4.00 & 4.00 & 3.50 & 3.50 & 3.50 & 3.00 & 3.00 \\
\hline Contol & 4.00 & 3.00 & 2.83 & 2.00 & 2.00 & 2.00 & 2.50 & 2.50 & 2.50 & 1.50 & 1.50 \\
\hline Mean & 4.00 & 3.22 & 3.28 & 3.00 & 3.17 & 3.17 & 3.00 & 3.00 & 2.83 & 2.50 & 2.33 \\
\hline LSD\% & - & 0.30 & 0.30 & - & - & - & - & - & - & - & - \\
\hline
\end{tabular}

Table 5 Effect of plant extract and variety on marketability of tomato fruits during storage at wukari 2018

\begin{tabular}{|c|c|c|c|c|c|c|c|c|c|c|c|}
\hline Treatment & Day4 & Day6 & Day8 & Day10 & Day12 & Day14 & Day16 & Day18 & Day20 & Day22 & Day24 \\
\hline \multicolumn{12}{|l|}{ Variety } \\
\hline Seria & 19.00 & 18.00 & 16.00 & 14.00 & 11.00 & 8.33 & 6.33 & 4.33 & 3.33 & 3.00 & 3.00 \\
\hline Tangino & 18.00 & 17.00 & 15.00 & 13.00 & 9.67 & 7.00 & 5.00 & 3.00 & 1.67 & 1.11 & 1.11 \\
\hline $\operatorname{LSD}(5 \%)$ & - & - & - & - & - & - & - & - & - & 0.24 & 0.24 \\
\hline \multicolumn{12}{|c|}{ Plant extract } \\
\hline Neem & 20.00 & 17.50 & 15.50 & 13.50 & 10.50 & 8.00 & 6.00 & 4.00 & 3.00 & 2.00 & 2.50 \\
\hline Ginger & 20.00 & 19.50 & 17.50 & 15.50 & 12.50 & 9.50 & 7.50 & 5.50 & 4.00 & 3.00 & 3.50 \\
\hline Contol & 16.50 & 15.50 & 13.50 & 11.50 & 8.00 & 5.00 & 3.50 & 1.50 & 0.50 & 0.67 & 0.67 \\
\hline Mean & 18.50 & 17.50 & 15.50 & 13.50 & 10.33 & 7.67 & 5.67 & 3.67 & 2.50 & 2.06 & 2.06 \\
\hline LSD\% & - & - & - & - & - & - & - & - & - & - & - \\
\hline
\end{tabular}

